\title{
Analisis tipe gaya kepemimpinan yang berpengaruh terhadap kinerja karyawan PT AyoMedia Network
}

\author{
Winata Handojo* \\ Program Magister Manajemen Universitas Kristen Maranatha, \\ Jl. Prof. drg. Surya Sumantri, M.P.H No. 65 Bandung \\ winatahand11@gmail.com \\ Amani Ahmed Sulaiman Al Juhani \\ Program Magister Manajemen Universitas Kristen Maranatha, \\ Jl. Prof. drg. Surya Sumantri, M.P.H No. 65 Bandung \\ amanijuhani.al@gmail.com \\ Desi Indah Nur Apiani \\ Program Magister Manajemen Universitas Kristen Maranatha, \\ Jl. Prof. drg. Surya Sumantri, M.P.H No. 65 Bandung \\ dessy.indah92@gmail.com \\ Johan Johan \\ Program Magister Manajemen Universitas Kristen Maranatha, \\ Jl. Prof. drg. Surya Sumantri, M.P.H No. 65 Bandung \\ joe247days@gmail.com \\ *Penulis Korespondensi
}

Submitted: Oct 15, 2020; Reviewed: Oct 17, 2020; Accepted: May 04, 2021

\begin{abstract}
Ayo Media Network is one of the media companies that has successfully adapted to the development of technology and communication and has an excellent performance in providing news and other content. The performance is influenced by various factors, where one of the most important is the leadership style shown by the leader which consists of the leadership style of instructive, consultative, participation, and delegation. The purpose of this study was to find out the influence of each leadership style on employee performance at Ayo Media Network. Ayo Media Network has 91 workers who are the object and research respondents. The research methods used in this research were descriptive and explanatory. The results obtained that there is no influence between the leadership style of instructive and consultative on employee performance, while the leadership style of participation and delegation has a positive influence on employee performance.
\end{abstract}

Keywords: consultative style; delegation style; employee performance; instructive style; leadership style; participation style

Abstrak: Ayo Media Network merupakan salah satu perusahaan media yang berhasil beradaptasi dengan perkembangan teknologi dan komunikasi dan memiliki kinerja yang sangat baik dalam 
penyediaan berita maupun konten lainnya. Kinerja tersebut dipengaruhi oleh berbagai macam faktor, yang mana salah satu yang terpenting adalah gaya kepemimpinan yang ditunjukkan oleh pemimpinnya yang terdiri dari gaya kepemimpinan instruksi, konsultasi, partisipasi, dan delegasi. Tujuan penelitian ini adalah mencari tahu pengaruh dari masing-masing gaya kepemimpinan terhadap kinerja karyawan di Ayo Media Network. Ayo Media Network memiliki 91 orang tenaga kerja yang menjadi objek dan responden penelitian. Metode penelitian yang digunakan dalam penelitian ini adalah deskriptif dan eksplanasi. Hasil penelitian yang didapatkan adalah tidak adanya pengaruh gaya kepemimpinan instruksi dan konsultasi terhadap kinerja karyawan, sedangkan gaya kepemimpinan partisipasi dan delegasi memiliki pengaruh yang positif terhadap kinerja karyawan.

Kata Kunci: gaya kepemimpinan; kepemimpinan delegasi; kepemimpinan instruksi; kepemimpinan konsultasi; kepemimpinan partisipasi; kinerja karyawan

\section{PENDAHULUAN}

Perkembangan teknologi dan globalisasi menyebabkan perusahaan yang bergerak dalam industri media massa mengalami perubahan yang sangat esktrem, yang mana hampir seluruh media konvensional seperti radio, koran/ majalah/ media tertulis lainnya, dan televisi mulai ditinggalkan oleh para konsumen yang beralih ke media daring. Tidak sedikit pula perusahan media yang tidak berhasil dalam peralihan tersebut dan pada akhirnya mengalami kebangkrutan atau berhenti cetak di Indonesia. Perusahaan media seperti Sinar Harapan, Soccer, Harian Bola, Tech Life, Tempo Minggu, Indonesia Finance Today, dan Jakarta Globe terpaksa berhenti terbit karena tidak siap dan tidak mampu dalam menghadapi arus perubahan yang serba daring.

Salah satu perusahaan media yang berhasil dalam beradaptasi dalam perkembangan media digital adalah Ayo Media Network. Ayo Media Network merupakan salah satu perusahaan media terbesar di Jawa Barat dengan tenaga kerja sebanyak 91 orang dan memiliki belasan portal berita yang saling terintegrasi dan menjadi salah satu portal berita digital terbaik di Jawa Barat.

Keberhasilan Ayo Media Network dalam menghadapi arus perubahan sekalipun tidak serta merta menghilangkan permasalahan lain yang muncul. Permasalahan seperti persaingan yang lebih ketat di dalam industri media daring, karena tidak adanya batasan fisik serta batasan cakupan, menyebabkan seluruh perusahaan dapat melakukan penetrasi terhadap pangsa pasar dari perusahaan pesaingnya. Situasi ini diperparah dengan meningkatnya jurnalisme warga yang tidak terikat pada perusahaan media (tidak menjadi bagian dan tidak melaporkan beritanya di suatu perusahaan media), sehingga menyebabkan arus berita menjadi lebih kencang dan pesat.

Menghadapi persaingan tersebut, Ayo Media Network dituntut untuk berkinerja dengan lebih baik dengan cara menghasilkan suatu berita yang bukan hanya menarik, namun juga berintegritas dan sesuai dengan fakta dan mampu menjangkau seluruh lapisan masyarakat. Kinerja di dalam perusahaan media pada umumnya lebih menitikberatkan kepada kualitas dibandingkan kuantitas, karena produk dari perusahaan media merupakan suatu konten berita yang muncul dari proses kreativitas dan intelektual tenaga kerjanya.

Tinggi atau rendahnya kinerja suatu perusahaan media ditentukan atau dipengaruhi oleh banyak sekali faktor, namun salah satu yang dianggap paling penting adalah faktor gaya kepemimpinan yang ditampilkan oleh pemimpin di dalam perusahaan media tersebut. Gaya kepemimpinan merupakan derajat seorang pemimpin mendelegasikan autoritasnya, jenis kekuasaan yang digunakan olehnya, hubungan dengan tenaga kerjanya, serta tinggi atau rendahnya tanggung jawab yang ditunjukkan oleh seorang pemimpin dalam perusahaan (Mawoli et al., 2013).

Gaya kepemimpinan seringkali disalah artikan sebagai kemampuan seorang pemimpin dalam mengatur atau menggunakan kekuasaannya, sehingga seringkali menimbulkan kondisi yang mana banyak perusahaan yang diatur secara berlebihan dan dipimpin secara berkekurangan, terlalu banyak perintah dan kontrol, dan terlalu sedikit motivasi dan kreativitas sehingga pada akhirnya mengalami kegagalan (Kotter, 2014). Oleh karenanya, menentukan gaya kepemimpinan yang sesuai merupakan sesuatu yang penting dan sulit (Manning \& Curtis, 2012), menentukan gaya kepemimpinan dikatakan sulit karena dipandang sebagai suatu kompetensi yang didapatkan, yang dipengaruhi oleh banyak faktor, yang mana lingkungan dan keadaan merupakan salah satu yang dominan. Berdasarkan 
pandangan ini, maka kepemimpinan dilihat sebagai suatu fenomena sosial dan bukan sebagai sifat individu.

Jenis-jenis gaya kepemimpinan berbeda-beda dari satu penelitian ke penelitian lainnya karena setiap peneliti memiliki identifikasi masing-masing, namun pada umumnya gaya kepemimpinan terbagi menjadi empat macam, yaitu kepemimpinan instruksi, kepemimpinan konsultasi, kepemimpinan partisipasi, dan kepemimpinan delegasi. Keempat jenis kepemimpinan ini didapatkan dan mengacu kepada penelitian mengenai gaya kepemimpinan oleh Iqbal et al. (2015), Ing'ollan \& Roussel (2017), Siswanto \& Hamid (2017), Saputro \& Siagian (2017), serta Waruwu \& Yunita (2019).

Uraian di atas telah sesuai dengan hasil penelitian dari Khairizah et al. (2015), Siswanto \& Hamid (2017), Jamaludin (2017), Saputro \& Siagian, (2017), Maryam (2017), Fajrin \& Susilo (2018), serta Kurniawan (2018) yang menjelaskan bahwa gaya kepemimpinan memiliki pengaruh signifikan terhadap kinerja karyawan, namun objek dalam penelitian tersebut pada umumnya adalah perusahaan manufaktur dan meskipun terdapat beberapa penelitian yang mengambil perusahaan jasa sebagai objek penelitian, secara umum belum ada penelitian yang mengambil perusahaan media sebagai objek penelitian utamanya, sehingga penelitian ini diharapkan dapat mengisi kekosongan tersebut serta mengonfirmasi hasil penelitian sebelumnya.

Uraian mengenai variabel penelitian di atas dapat digambarkan ke dalam suatu model penelitian sebagai berikut:

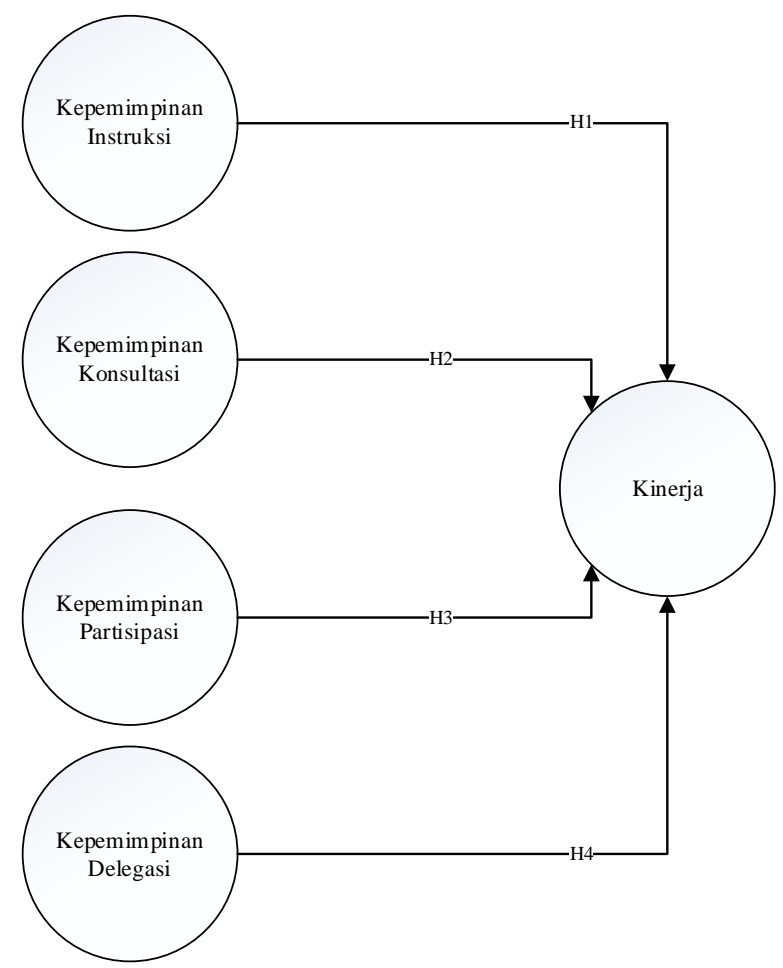

Gambar 1. Model penelitian

Sumber: Kerangka pemikiran peneliti

Gaya kepemimpinan instruksi merupakan gaya kepemimpinan yang menitikberatkan kepada peran pemimpin dalam memberi batasan peran tenaga kerjanya dan memberitahukan kepada mereka tugas mereka, bagaimana cara melaksanakan tugas tersebut, dan di mana mereka harus mengerjakannya (Thoha, 2012). Gaya kepemimpinan instruksi mampu memengaruhi kinerja tenaga kerja karena setiap arahan atau instruksi yang diberikan oleh pemimpin pada umumnya mengikat dan harus dipatuhi, sehingga kinerja akan sangat bergantung kepada instruksi-instruksi tersebut. Ketika instruksi berhasil dilaksanakan dengan baik, maka akan tercipta pengaruh yang positif; namun apabila instruksi gagal untuk dilaksanakan, maka pengaruh yang tercipta adalah negatif (Habeeb \& Ibrahim, 2017; Ing'ollan \& Roussel, 2017; Waruwu \& Yunita, 2019).

$\mathrm{H}_{1}$ : Kepemimpinan instruksi memiliki pengaruh terhadap kinerja. 
Gaya kepemimpinan konsultasi merupakan pengembangan dari gaya kepemimpinan instruksi, yang mana meskipun masih terdapat arahan dan pengambilan keputusan yang sepihak dari pemimpin, namun tercipta komunikasi dua arah dan dukungan terhadap umpan balik dari tenaga kerja, seperti ide, saran, dan kritik. Gaya kepemimpinan ini juga dipandang mampu memengaruhi kinerja tenaga kerja karena sifatnya yang berimbang antara autrokratik dan demokratik, maka potensi dari pengaruh yang diberikan oleh gaya kepemimpinan ini terhadap kinerja pada umumnya lebih besar dari gaya kepemimpinan lainnya (Khairizah et al., 2015; Habeeb \& Ibrahim, 2017; Ing'ollan \& Roussel, 2017; Waruwu \& Yunita, 2019).

$\mathrm{H}_{2}$ : Kepemimpinan konsultasi memiliki pengaruh terhadap kinerja.

Gaya kepemimpinan partisipasi merupakan gaya kepemimpinan yang menekankan kepada partisipasi pemimpin dan tenaga kerja untuk saling bertukar pendapat, ide, maupun saran dalam memecahkan suatu masalah dan menyelesaikan suatu pekerjaan. Gaya kepemimpinan ini, menurut Habeeb \& Ibrahim (2017), Ing'ollan \& Roussel (2017), serta Waruwu \& Yunita (2019), memiliki pengaruh yang secara umum lebih condong ke arah positif terhadap kinerja karyawan karena sifatnya yang mendorong partisipasi kedua belah pihak, maka semakin tinggi peluang suatu pekerjaan berhasil terselesaikan dengan sangat baik.

$\mathrm{H}_{3}$ : Kepemimpinan partisipasi memiliki pengaruh terhadap kinerja.

Kepemimpinan delegasi menitikberatkan kepada pembagian kekuasaan, tugas, dan tanggung jawab yang dimiliki oleh pemimpin kepada tenaga kerjanya, yang memiliki kemampuan, kualifikasi, serta perilaku yang sesuai di mata pemimpinnya. Kepemimpinan delegasi memberikan kebebasan yang tinggi kepada tenaga kerja, terutama yang mendapatkan mandat dan tanggung jawab dari pemimpin. Kebebasan ini menyebabkan timbulnya kreativitas dari tenaga kerja yang berkontribusi positif terhadap kinerja mereka secara keseluruhan. Penelitian oleh Khairizah et al. (2015), Habeeb \& Ibrahim (2017), Ing'ollan \& Roussel (2017), serta Waruwu \& Yunita (2019) menemukan bahwa kepemimpinan delegasi merupakan jenis kepemimpinan yang memiliki pengaruh yang positif terhadap kinerja tenaga kerja.

$\mathrm{H}_{4}$ : Kepemimpinan delegasi memiliki pengaruh terhadap kinerja.

\section{METODE}

Metode penelitian yang digunakan di dalam penelitian ini merupakan kombinasi dari dua metode, yaitu metode deskriptif dan ekspalanasi. Metode deskriptif digunakan untuk memberikan penjelasan mengenai kondisi atau keadaan dari suatu variabel penelitian, sedangkan metode eksplanasi digunakan untuk mencari apakah terdapat suatu hubungan atau pengaruh di antara variabel-variabel independen terhadap variabel dependen di dalam suatu penelitian.

Populasi dalam penelitian ini adalah seluruh tenaga kerja non manajerial Ayo Media Network yang berjumlah 91 orang. Dikarenakan jumlah populasi yang tidak terlalu besar dan tidak menimbulkan kesulitan bagi peneliti, maka diputuskan bahwa keseluruhan populasi sebesar 91 orang akan diambil sebagai responden penelitian. Pemilihan tenaga kerja non manajerial sebagai populasi dilakukan untuk memastikan bahwa data yang didapatkan tidak bias, karena dengan mengambil data dari tenaga kerja manajerial dikhawatirkan akan tercipta data yang bias karena topik dari penelitian ini adalah tentang bentuk kepemimpinan yang diterapkan oleh tenaga kerja manajerial perusahaan.

\subsection{Kepemimpinan instruksi}

Kepemimpinan instruksi merupakan tipe kepemimpinan yang menekankan kepada instruksi atau direksi dari seorang pemimpin yang sistematis mengenai kebijakan, kegiatan, peraturan, dan arah perusahaan (Khairizah et al., 2015). Karena sifatnya yang sangat dependen dengan pemimpin, maka tingkat intelektual serta pengalaman pemimpin menjadi kunci keberhasilan dalam tipe kepemimpinan ini. Untuk mengidentifikasi dan menilai kepemimpinan instruksi dan gaya kepemimpinan lainnya di dalam perusahaan, maka digunakan indikator-indikator yang bersumber dari penelitian oleh Iqbal et al. (2015), Ing'ollan \& Roussel (2017), Siswanto \& Hamid (2017), Saputro \& Siagian (2017), serta Waruwu \& Yunita (2019): 
1. Kejelasan pekerjaan

Kepemimpinan instruksi menekankan pada deskripsi dan spesifikasi mengenai suatu pekerjaan secara detil dan jelas, agar setiap tenaga kerja yang menempati suatu posisi atau mengerjakan suatu pekerjaan dapat melakukannya dengan baik.

2. Standar dan instruksi pengerjaan pekerjaan

Standar operasional dan instruksi tertulis mengenai bagaimana suatu pekerjaan harus dilakukan merupakan salah satu ciri khas dari jenis kepemimpinan instruksi, dengan harapan pekerjaan atau aktivitas yang dilakukan di dalam suatu perusahaan mampu menghasilkan kuantitas dan kualitas yang ideal.

3. Pelaporan secara teratur, rutin, dan runtut

Laporan hasil pekerjaan yang teratur, rutin, dan runtut adalah evaluasi dari instruksi yang diberikan yang menilai apakah suatu pekerjaan telah dilakukan sesuai dengan standar dan instruksi yang seharusnya dan mengidentifikasi apabila terjadi masalah atau kegagalan.

4. Ketepatan waktu pelaporan

Kepemimpinan instruksi sangat menekankan kepada orientasi terhadap waktu, setiap pekerjaan harus dikerjakan dan dilaporkan sesuai dengan waktu yang seharusnya, agar tidak memperlambat instruksi selanjutnya.

\subsection{Kepemimpinan konsultasi}

Kepemimpinan konsultasi adalah tipe kepemimpinan yang menonjolkan interaksi di antara tenaga kerja dengan pemimpin, yang berbentuk diskusi ataupun pertukaran pemikiran lainnya (Thoha, 2012). Kepemimpinan ini mendorong tenaga kerja untuk berkontribusi dalam pembuatan kebijakan atau keputusan, namun tidak berpengaruh terhadap pengambilan keputusan akhir, yang mana tetap berada di tangan pemimpin. Untuk mengidentifikasi dan menilai kepemimpinan konsultasi dan gaya kepemimpinan lainnya di dalam perusahaan, maka digunakan indikator-indikator yang bersumber dari penelitian oleh Iqbal et al. (2015), Ing'ollan \& Roussel (2017), Siswanto \& Hamid (2017), Saputro \& Siagian (2017), serta Waruwu dan Yunita (2019):

1. Penentuan tujuan dalam setiap kegiatan, aktivitas, dan pekerjaan

Setiap kegiatan, aktivitas, maupun pekerjaan di dalam suatu perusahaan memiliki tujuan serta manfaat tersendiri, sehingga identifikasi dan penentuan tujuan merupakan langkah awal yang harus dilakukan sebelum memulai kegiatan, aktivitas, dan pekerjaan tersebut.

2. Keterbukaan dan kesediaan untuk diskusi

Diskusi antar rekan kerja maupun dengan atasan merupakan salah satu sarana yang konstruktif dalam pengembangan perusahaan, sehingga setiap anggota sedapat mungkin dihimbau serta didorong untuk melakukan diskusi secara intensif.

3. Penyampaian harapan terhadap suatu pelaksanaan pekerjaan

Sebelum suatu pekerjaan dilakukan, seorang pemimpin harus menyampaikan kepada tenaga kerjanya mengenai harapannya terhadap pelaksanaan dan hasil dari pekerjaan yang akan dilakukan dan menerima umpan balik dari tenaga kerjanya, agar seorang pemimpin dapat memahami apakah harapan tersebut feasible atau tidak.

4. Dukungan terhadap bawahan

Pemimpin yang menerapkan kepemimpinan konsultasi memberikan dukungan penuh kepada anak buahnya untuk mengembangkan dirinya melalui berbagai macam kegiatan, seperti pelatihan maupun diskusi.

\subsection{Kepemimpinan partisipasi}

Kepemimpinan partisipasi memiliki beberapa kesamaan dengan kepemimpinan konsultasi, yang mana keduanya sama-sama menitikberatkan kepada partisipasi aktif dari tenaga kerja dengan pemimpinnya, namun dalam kepemimpinan partisipasi, tenaga kerja memiliki lebih banyak kebebasan dan memiliki andil dalam penentuan kebijakan-kebijakan perusahaan, karena peran pemimpin dalam gaya kepemimpinan ini lebih kepada fasilitator dibandingkan pembuat keputusan atau aturan (Iqbal et al., 2015). Untuk mengidentifikasi dan menilai kepemimpinan partisipasi dan gaya kepemimpinan lainnya di dalam perusahaan, maka digunakan indikator-indikator yang bersumber dari penelitian oleh Iqbal et 
al. (2015), Ing'ollan \& Roussel (2017), Siswanto \& Hamid (2017), Saputro \& Siagian (2017), serta Waruwu \& Yunita (2019):

1. Intensitas bawahan menyampaikan masukan, saran, ide, dan inovasi

Kepemimpinan partisipasi memberikan kebebasan penuh kepada tenaga kerjanya untuk memberikan masukan, saran, ide, maupun inovasi kepada seorang pemimpin, sehingga idealnya dalam kepemimpinan ini intensitas penyampaian tersebut jauh lebih tinggi dibandingkan jenis kepemimpinan lainnya.

2. Mempertimbangkan masukan, saran, ide, dan inovasi dari bawahan

Pemimpin yang partisipatif tidak hanya menerima masukan, saran, ide, atau inovasi dari bawahannya, namun juga mempertimbangkan dan mengakomodasinya sebisa mungkin.

3. Tersedianya kesempatan bagi bawahan untuk mengembangkan diri

Partisipasi dari tenaga kerja dimaksudkan agar tenaga kerja tersebut dapat mengembangkan dirinya sendiri, dalam lingkungan yang terbuka dan komunikatif seperti dalam kepemimpinan partisipasi, setiap tenaga kerja memiliki peluang dan kesempatan yang sama untuk berkembang.

4. Kepercayaan yang tinggi terhadap bawahan

Pemimpin partisipatif memiliki kepercayaan yang tinggi terhadap kemampuan dan kredibilitas tenaga kerjanya, mereka lebih berani untuk memberikan kekuasaan ataupun tanggung jawab yang lebih besar kepada tenaga kerjanya.

\subsection{Kepemimpinan delegasi}

Kepemimpinan delegasi memindahkan fungsi-fungsi kepemimpinan, seperti pengambilan keputusan atau arahan kepada tenaga kerja dengan harapan tenaga kerja tersebut dapat menyelesaikan permasalahannya sendiri (Prasetya et al., 2017). Pemimpin dalam gaya kepemimpinan ini berfungsi sebagai mentor atau guru yang memberikan bimbingan serta pengetahuan kepada tenaga kerjanya dan memberikan kepercayaan serta tanggung jawab untuk membuat keputusan. Untuk mengidentifikasi dan menilai kepemimpinan delegasi dan gaya kepemimpinan lainnya di dalam perusahaan, maka digunakan indikator-indikator yang bersumber dari penelitian oleh Iqbal et al. (2015), Ing'ollan \& Roussel (2017), Siswanto \& Hamid (2017), Saputro \& Siagian (2017), serta Waruwu \& Yunita (2019):

1. Memberikan bimbingan serta pembinaan kepada bawahan

Pemimpin sebelum mendelegasikan tugas, wewenang, dan tanggung jawabnya akan memberikan pelatihan, bimbingan, dan pembinaan kepada tenaga kerjanya agar siap menerima tugas, wewenang, dan tanggung jawab tersebut.

2. Bawahan diberi kebebasan untuk mengambil inisiatif sendiri

Sebagai pihak yang memiliki tanggung jawab dan wewenang, setiap tenaga kerja diberikan kebebasan untuk mengambil inisiatif dalam melakukan suatu pekerjaan, kebijakan ini mendorong setiap tenaga kerja untuk berpikir secara kreatif dan inovatif serta mengembangkan kemampuan dirinya sendiri.

3. Bawahan memiliki wewenang dan tanggung jawab untuk mengambil keputusan yang mendesak Salah satu kelebihan dari kepemimpinan delegasi adalah kemampuan tenaga kerja untuk mengambil suatu keputusan yang sangat mendesak karena mereka diberi wewenang dan tanggung jawab.

4. Tingkat kepercayaan terhadap bawahan

Karena pemimpin mendelegasikan wewenang dan tanggung jawabnya kepada tenaga kerja, maka sudah seharusnya terjadi jalinan kepercayaan yang erat di antara pemimpin dan tenaga kerjanya, tanpa adanya kepercayaan sangat mustahil kepemimpinan delegasi dapat dilakukan.

\subsection{Kinerja}

Kinerja merupakan suatu hasil dari suatu pekerjaan atau aktivitas produksi yang dilakukan oleh seseorang serta dinilai secara kuantitas dan kualitas yang dihasilkan atau dicapai oleh seorang tenaga kerja, yang disesuaikan dengan tanggung jawab yang dimiliki oleh orang tersebut (Mangkunegara, 2011). Hasil kerja harus memiliki kemampuan untuk diukur secara konkrit untuk menghasilkan suatu bukti (Sedarmayanti, 2017). Kesimpulannya, kinerja adalah output yang dihasilkan oleh seorang 
anggota organisasi yang dinilai atas dasar jenis pekerjaan dan tanggung jawab, serta memiliki besaran yang dapat diukur sebagai bahan pembuktian.

Kinerja adalah keseluruhan output dari suatu pekerjaan atau kegiatan di dalam perusahaan, yang hasilnya secara kuantitas dan kualitas sesuai dengan standar yang telah ditentukan sebelumnya (Bangun, 2012). Berdasarkan definisi tersebut, maka indikator yang ditentukan untuk menilai kinerja adalah:

1. Kuantitas kerja telah sesuai dengan tanggung jawab dan tuntutan perusahaan

Kuantitas kerja merupakan seberapa banyak jumlah barang atau jasa yang berhasil diproduksi atau dihasilkan dalam suatu periode tertentu, suatu kinerja yang baik mampu menghasilkan kuantitas yang sesuai dengan tanggung jawab dan tuntutan perusahaan.

2. Pekerjaan dapat diselesaikan sesuai dengan tenggat waktu

Ketepatan waktu menjadi salah satu indikator terpenting dari kinerja, karena pada dasarnya perusahaan memiliki tanggung jawab kepada distributor ataupun konsumen untuk memberikan produk atau jasa yang telah dipesan sebelumnya sesuai dengan waktu yang telah disepakati, sehingga proses produksi produk atau jasa harus diselesaikan sesuai dengan tenggat waktu.

3. Hasil kerja memiliki kualitas yang sesuai dengan standar perusahaan

Selain kuantitas, terdapat kualitas produk atau jasa yang harus diperhatikan, dalam suatu kinerja yang baik, produk atau jasa yang dihasilkan memiliki kualitas yang baik dan telah sesuai dengan standar perusahaan.

4. Penggunaan kemampuan dan pengetahuan untuk menyelesaikan suatu pekerjaan

Orientasi kepada hasil dan waktu harus ditunjang oleh kemampuan dan pengetahuan dari tenaga kerja agar terjadi pengembangan diri maupun perusahaan, karena suatu perusahaan harus bergerak secara dinamis dan maju sehingga kemampuan dan pengetahuan tenaga kerja harus dimanfaatkan untuk menyelesaikan suatu pekerjaan.

5. Penyelesaian kerja sesuai dengan standar yang ditentukan perusahaan

Suatu pekerjaan yang memenuhi standar yang telah ditentukan perusahaan merupakan suatu bentuk dari kinerja yang ideal, karena standar yang telah ditentukan oleh perusahaan harus memenuhi unsur keselamatan dan kesehatan kerja tenaga kerja, sehingga suatu pekerjaan yang dilakukan sesuai dengan standar dapat meminimalisir terjadinya kecelakan kerja maupun kegagalan produksi.

\subsection{Instrumen penelitian}

Penelitian ini memakai data primer sebagai instrumen penelitian utama, yang didapatkan melalui pembagian kuesioner terhadap responden penelitian. Setiap pernyataan di dalam kuesioner dibuat dan disusun sesuai dengan indikator dari masing-masing variabel penelitian dan jawabannya diukur dengan menggunakan skala Likert 5 poin, yang terdiri dari sangat tidak setuju (1), tidak setuju (2), netral (3), setuju (4), dan sangat setuju (5). Responden penelitian yang mengisi kuesioner tidak diperbolehkan menjawab di luar kelima poin di atas, sehingga desain item-item pertanyaan dalam kuesioner penelitian ini bersifat tertutup.

\subsection{Teknik analisis data}

Sebelum dilakukan analisis data, maka peneliti akan melakukan pengujian asumsi klasik untuk membuktikan apakah model penelitian yang digunakan dalam penelitian ini telah layak untuk dijadikan bahan penelitian. Adapun uji asumsi klasik yang dipakai dalam penelitian ini terdiri dari uji normalitas (1-S Kolmogorov Smirnov), uji multikolinearitas (Tolerance dan VIF), serta uji heterokedastisitas (Uji Glesjer).

Sebagai suatu penelitian kuantitatif, maka penelitian ini menggunakan teknik analisis data dan metode statistik yang telah tersedia. Teknik analisa data dalam penelitian ini adalah regresi linear berganda. Regresi menunjukkan pengaruh antara dua atau lebih variabel independen terhadap variabel dependen, yang dapat berbentuk pengaruh positif ataupun negatif, yang kemudian dari hasil analisis tersebut akan ditarik persamaan regresinya, yang berbentuk sebagai berikut:

$$
\mathrm{Y}=\mathrm{a}+\mathrm{b}_{1} \mathrm{X}_{1}+\mathrm{b}_{2} \mathrm{X}_{2}+\mathrm{b}_{3} \mathrm{X}_{3}+\mathrm{b}_{4} \mathrm{X}_{4}
$$

Keterangan:

Y

$$
\text { : Kinerja karyawan }
$$




$\begin{array}{ll}\mathrm{a} & : \text { Konstanta } \\ \mathrm{b}_{1}, \mathrm{~b}_{2}, \mathrm{~b}_{3}, \text { dan } \mathrm{b}_{4} & : \text { Koefisien regresi } \\ \mathrm{X}_{1} & : \text { Kepemimpinan instruksi } \\ \mathrm{X}_{2} & : \text { Kepemimpinan konsultasi } \\ \mathrm{X}_{3} & : \text { Kepemimpinan partisipasi } \\ \mathrm{X}_{4} & : \text { Kepemimpinan delegasi }\end{array}$

\subsection{Pengujian hipotesis}

Pengujian hipotesis dilakukan dengan mempertimbangkan hipotesis statistik di bawah ini:

$\mathrm{H}_{0}$ : sig. $>0,05$, maka tidak terdapat pengaruh signifikan di antara variabel independen terhadap variabel dependen.

Ha: sig $\leq 0,05$, maka terdapat pengaruh yang signifikan di antara variabel independen terhadap variabel dependen.

\section{HASIL DAN PEMBAHASAN}

\subsection{Pengujian validitas}

Tabel 1. Uji validitas

\begin{tabular}{cccc}
\hline Item & Pearson Correlation & $\mathrm{r}_{\text {tabel }}$ & Keterangan \\
\hline KI1 & 0,715 & 0,203 & Valid \\
KI2 & 0,769 & 0,203 & Valid \\
KI3 & 0,758 & 0,203 & Valid \\
KI4 & 0,774 & 0,203 & Valid \\
KI5 & 0,764 & 0,203 & Valid \\
KI6 & 0,793 & 0,203 & Valid \\
KK1 & 0,801 & 0,203 & Valid \\
KK2 & 0,808 & 0,203 & Valid \\
KK3 & 0,833 & 0,203 & Valid \\
KK4 & 0,770 & 0,203 & Valid \\
KK5 & 0,609 & 0,203 & Valid \\
KK6 & 0,710 & 0,203 & Valid \\
KP1 & 0,573 & 0,203 & Valid \\
KP2 & 0,763 & 0,203 & Valid \\
KP3 & 0,800 & 0,203 & Valid \\
KP4 & 0,748 & 0,203 & Valid \\
KP5 & 0,737 & 0,203 & Valid \\
KP6 & 0,712 & 0,203 & Valid \\
KD1 & 0,518 & 0,203 & Valid \\
KD2 & 0,795 & 0,203 & Valid \\
KD3 & 0,827 & 0,203 & Valid \\
KD4 & 0,697 & 0,203 & Valid \\
KD5 & 0,817 & 0,203 & Valid \\
KD6 & 0,827 & 0,203 & Valid \\
K1 & 0,790 & 0,203 & Valid \\
K2 & 0,757 & 0,203 & Valid \\
K3 & 0,788 & 0,203 & Valid \\
K4 & 0,769 & 0,203 & Valid \\
K5 & 0,732 & 0,203 & Valid \\
\hline Sub & &
\end{tabular}

Sumber: Hasil pengolahan data

Pengujian validitas yang didasarkan kepada tabel di atas mampu memberikan penjelasan bahwa seluruh item di setiap variabel penelitian memiliki nilai Pearson Correlation lebih besar dari 0,203, 
sehingga dapat dijelaskan bahwa masing-masing pernyataan dalam setiap variabel penelitian telah memenuhi unsur validitas dan telah layak untuk digunakan dalam penelitian.

\subsection{Pengujian reliabilitas}

Tabel 2. Uji reliabilitas

\begin{tabular}{cccc}
\hline Variabel & Cronbach Alpha & $\begin{array}{c}\text { Jumlah } \\
\text { Pernyataan }\end{array}$ & Keterangan \\
\hline X1 (KI) & 0,855 & 6 & Reliabel \\
X2 (KK) & 0,848 & 6 & Reliabel \\
X3 (KP) & 0,816 & 6 & Reliabel \\
X4 (KD) & 0,848 & 6 & Reliabel \\
Y (K) & 0,822 & 5 & Reliabel \\
\hline
\end{tabular}

Sumber: Hasil pengolahan data

Tabel di atas memberikan hasil berupa nilai Cronbach Alpha dari variabel kepemimpinan instruksi adalah sebesar 0,855, variabel kepemimpinan konsultasi sebesar 0,848, variabel kepemimpinan partisipasi sebesar 0,816 , variabel kepemimpinan delegasi sebesar 0,848 , dan variabel kinerja sebesar 0,822. Dikarenakan nilai Cronbach Alpha dari seluruh variabel penelitian telah lebih besar dari 0,7, maka dapat ditarik suatu kesimpulan sehubungan dengan reliabilitas bahwa seluruh variabel independen dan dependen di dalam penelitian dapat dipertanggungjawabkan tingkat reliabilitasnya dan layak untuk digunakan dalam penelitian.

\subsection{Pengujian asumsi klasik}

Tabel 3. Uji normalitas

One-Sample Kolmogorov-Smirnov Test

\begin{tabular}{llr}
\hline & & Ustd. Residual \\
\hline $\mathrm{N}$ & & 91 \\
Normal Parameters & Mean & 0,0000000 \\
& Std. Dev. & 0,37892737 \\
Most Extreme Differences & Absolute & 0,081 \\
& + & 0,053 \\
& - & $-0,081$ \\
Test Stat. & & 0,081 \\
Asymp. Sig. (2-tailed) & & $0,182^{\mathrm{c}}$ \\
\hline
\end{tabular}

Sumber: Hasil pengolahan data

Nilai asymp. sig. yang didapatkan dari pengujian Kolmogorov-Smirnov adalah sebesar 0,182. Karena nilai asymp. sig. tersebut lebih besar dari 0,05, maka dapat ditarik suatu kesimpulan bahwa distribusi variabel residual dalam instrumen penelitian telah normal dan telah memenuhi asumsi normalitas.

Tabel 4. Uji heteroskedastisitas

\begin{tabular}{llccccc}
\hline & & \multicolumn{5}{c}{ Std. } \\
Model & & Ustd. Coefficients & Coefficients \\
Beta & $\mathrm{t}$ & Sig. \\
\hline 1 & (Constant) & 0,173 & 0,215 & & 0,804 & 0,423 \\
& RKI & 0,023 & 0,073 & 0,052 & 0,316 & 0,753 \\
& RKK & 0,122 & 0,079 & 0,294 & 1,542 & 0,127 \\
& RKP & $-0,070$ & 0,053 & $-0,162$ & $-1,324$ & 0,189 \\
& RKD & $-0,044$ & 0,087 & $-0,103$ & $-0,502$ & 0,617 \\
\hline
\end{tabular}

Sumber: Hasil pengolahan data

Nilai sig. yang didapatkan dari masing-masing variabel independen adalah 0,753 (kepemimpinan instruksi), 0,127 (kepemimpinan konsultasi), 0,189 (kepemimpinan partisipasi), dan 0,617 
(kepemimpinan delegasi). Seluruh nilai sig. tersebut lebih besar dari 0,05, oleh karena itu dapat ditarik suatu kesimpulan bahwa dalam model regresi penelitian tidak terjadi heteroskedastisitas, sehingga model regresi tersebut telah memenuhi asumsi heteroskedastisitas.

Tabel 5. Uji multikolinearitas

\begin{tabular}{|c|c|c|c|c|c|c|c|c|}
\hline \multirow[b]{2}{*}{ Mod } & & \multicolumn{2}{|c|}{ Ustd. Coefficients } & \multirow{2}{*}{$\begin{array}{c}\text { Std. } \\
\text { Coefficients } \\
\text { Beta }\end{array}$} & \multirow[b]{2}{*}{$\mathrm{t}$} & \multirow[b]{2}{*}{ Sig. } & \multicolumn{2}{|c|}{$\begin{array}{c}\text { Collinearity } \\
\text { Statistics }\end{array}$} \\
\hline & & $\mathrm{B}$ & Std. Error & & & & Tolerance & VIF \\
\hline \multirow[t]{5}{*}{1} & (Constant) & 1,247 & 0,349 & & 3,569 & 0,001 & & \\
\hline & RKI & 0,092 & 0,119 & 0,096 & 0,772 & 0,442 & 0,409 & 2,443 \\
\hline & RKK & $-0,068$ & 0,128 & $-0,076$ & $-0,531$ & 0,597 & 0,304 & 3,289 \\
\hline & RKP & 0,253 & 0,086 & 0,270 & 2,922 & 0,004 & 0,734 & 1,363 \\
\hline & RKD & 0,456 & 0,142 & 0,495 & 3,212 & 0,002 & 0,264 & 3,793 \\
\hline
\end{tabular}

Sumber: Hasil pengolahan data

Nilai VIF yang dari masing-masing variabel independen adalah 2,443 (kepemimpinan instruksi), 3,289 (kepemimpinan konsultasi), 1,363 (kepemimpinan partisipasi), dan 3,793 (kepemimpinan delegasi), sedangkan nilai dari Tolerance adalah 0,409 (kepemimpinan instruksi), 0,304 (kepemimpinan konsultasi), 0,734 (kepemimpinan partisipasi), dan 0,264 (kepemimpinan delegasi). Nilai seluruh VIF lebih rendah dari 10 dan nilai seluruh Tolerance lebih besar dari 0,10, oleh karena itu dapat ditarik suatu kesimpulan bahwa tidak terjadi multikolinearitas di antara variabel-variabel independennya dalam model regresi dan telah memenuhi asumsi multikolinearitas.

\subsection{Pengujian model regresi}

Tabel 6. Uji regresi

\begin{tabular}{|c|c|c|c|c|c|c|}
\hline \multirow[b]{2}{*}{ Model } & & \multicolumn{2}{|c|}{ Unstandardized Coefficients } & $\begin{array}{c}\text { Standardized } \\
\text { Coefficients }\end{array}$ & \multirow[b]{2}{*}{$\mathrm{t}$} & \multirow[b]{2}{*}{ Sig. } \\
\hline & & B & Std. Error & Beta & & \\
\hline 1 & (Constant) & 1,247 & 0,349 & & 3,569 & 0,001 \\
\hline & RKI & 0,092 & 0,119 & 0,096 & 0,772 & 0,442 \\
\hline & RKK & $-0,068$ & 0,128 & $-0,076$ & $-0,531$ & 0,597 \\
\hline & RKP & 0,253 & 0,086 & 0,270 & 2,922 & 0,004 \\
\hline & RKD & 0,456 & 0,142 & 0,495 & 3,212 & 0,002 \\
\hline
\end{tabular}

Sumber: Hasil pengolahan data

Pengujian regresi dilakukan dengan menggunakan uji t untuk mendapatkan nilai koefisien regresinya dan berdasarkan uji t tersebut maka dapat dijelaskan model regresi dalam penelitian ini adalah sebagai berikut:

$$
Y=1,247+0,092 X_{1}-0,068 X_{2}+0,253 X_{3}+0,456 X_{4}
$$

Model regresi tersebut menandakan bahwa nilai $\mathrm{Y}$ atau kinerja karyawan adalah 1,247 apabila diasumsikan bahwa seluruh nilai variabel-variabel lainnya adalah konstan atau 0 .

\subsection{Pengujian hipotesis}

Pengujian regresi atau uji t digunakan untuk membuktikan hipotesis statistik penelitian secara parsial atau masing-masing. Berdasarkan tabel uji t di atas, maka dapat dijelaskan bahwa:

1. $\mathrm{H}_{1}$ : sig. $=0,442$ atau > dari 0,05 , sehingga $\mathrm{H}_{01}$ diterima, sehingga dapat dijelaskan bahwa tidak terdapat pengaruh di antara variabel kepemimpinan instruksi terhadap kinerja karyawan.

2. $\mathrm{H}_{2}$ : sig. $=0,597$ atau > dari 0,05 , sehingga $\mathrm{H}_{02}$ diterima, sehingga dapat dijelaskan bahwa tidak terdapat pengaruh di antara variabel kepemimpinan konsultasi terhadap kinerja karyawan. 
3. $\mathrm{H}_{3}$ : sig. $=0,004$ atau $<$ dari 0,05 , sehingga $\mathrm{H}_{03}$ ditolak dan $\mathrm{Ha}_{3}$ diterima, sehingga dapat dijelaskan bahwa terdapat pengaruh di antara variabel kepemimpinan partisipasi terhadap kinerja karyawan dan ditemukan bahwa pengaruh tersebut berbentuk positif atau berbanding lurus.

4. $\mathrm{H}_{4}$ : sig. $=0,002$ atau < dari 0,05, sehingga $\mathrm{H}_{04}$ ditolak dan $\mathrm{Ha}_{4}$ diterima, sehingga dapat dijelaskan bahwa terdapat pengaruh di antara variabel kepemimpinan delegasi terhadap kinerja karyawan dan ditemukan bahwa pengaruh tersebut berbentuk positif atau berbanding lurus.

\subsection{Pengujian simultan}

Tabel 7. Uji ANOVA

\begin{tabular}{llccccc}
\hline Model & & Sum of & & & & \\
\hline 1 & Regression & 11,045 & 4 & 2,761 & 18,376 & $0,000^{\mathrm{b}}$ \\
& Residual & 12,923 & 86 & 0,150 & & \\
& Total & 23,967 & 90 & & & \\
\hline
\end{tabular}

Sumber: Hasil pengolahan data

Pengujian simultan dalam penelitian ini dilakukan dengan uji $\mathrm{F}$ atau yang secara umum dikenal dengan uji ANOVA, untuk mencari apakah terdapat pengaruh dari seluruh variabel independen dalam penelitian terhadap variabel dependennya atau disebut juga pengaruh simultan. Dari pengujian ANOVA tersebut, didapatkan nilai sig. lebih rendah dari 0,05 dan menandakan bahwa terdapat pengaruh simultan di antara variabel-variabel independen terhadap variabel dependen.

\subsection{Koefisien determinasi}

Tabel 8. Koefisien determinasi

\begin{tabular}{lcccc}
\hline Model & $\mathrm{R}$ & $R$ Square & $\begin{array}{c}\text { Adjusted } R \\
\text { Square }\end{array}$ & $\begin{array}{c}\text { Std. Error of } \\
\text { the Estimate }\end{array}$ \\
\hline 1 & $0,679^{\mathrm{a}}$ & 0,461 & 0,436 & 0,38764 \\
\hline
\end{tabular}

Sumber: Hasil pengolahan data

Koefisien determinasi memberikan gambaran mengenai tingkat atau besarnya kemampuan dari variabel-variabel independen penelitian dalam menjelaskan atau memberikan pengaruh terhadap variabel dependen di luar variabel-variabel independen lainnya yang tidak dibahas dan digunakan di dalam penelitian ini. Berdasarkan hasil pengolahan data, ditemukan bahwa nilai adjusted $R$ Square dalam penelitian ini adalah sebesar 0,436 atau $43,6 \%$, artinya seluruh variabel independen memiliki kemampuan sebesar 43,6\% untuk memberikan pengaruh terhadap kinerja karyawan, adapun sisanya sebesar 56,4\% dipengaruhi oleh variabel lain di luar penelitian.

\section{PEMBAHASAN}

Hasil pengolahan data memberikan gambaran yang jelas mengenai pengaruh dari masing-masing gaya kepemimpinan terhadap kinerja karyawan di AyoMedia Network, yang mana ditemukan bahwa gaya kepemimpinan instruksi dan konsultasi tidak memiliki pengaruh terhadap kinerja karyawan, sedangkan gaya kepemimpinan partisipasi dan delegasi memiliki pengaruh yang positif terhadap kinerja karyawan.

Kepemimpinan instruksi dalam penelitian ini tidak memiliki pengaruh terhadap kinerja karyawan karena dalam perusahaan media yang bergantung kepada kecepatan dan kejelian dari tenaga kerja untuk mendapatkan berita atau konten, menunggu instruksi atau arahan dari pemimpin atau pemimpin redaksi sangat menyita waktu dan menghambat proses jurnalistik, sehingga seringkali instruksi seringkali tidak dibutuhkan, terutama untuk pembuatan berita. Pengaruh ini tidak sesuai dengan hasil penelitian para peneliti sebelumnya, seperti Prasetya et al. (2017), Siswanto \& Hamid (2017), serta Otieno \& Njoroge (2019) yang menyatakan dalam hasil penelitiannya bahwa kepemimpinan instruksi memiliki pengaruh terhadap kinerja karyawan, namun sesuai dengan hasil penelitian oleh Khajeh 
(2018) yang menjelaskan bahwa dalam beberapa jenis perusahaan, gaya kepemimpinan instruksi yang autokratis tidak memiliki pengaruh terhadap kinerja karyawan.

Kepemimpinan konsultasi dalam penelitian ini ditemukan tidak memiliki pengaruh terhadap kinerja karyawan karena meskipun terdapat interaksi di antara tenaga kerja dengan pemimpin untuk mendapatkan ide dan kontribusi, namun untuk sebagian besar tugas dan pekerjaan dilakukan secara independen oleh tenaga kerjanya, sehingga interaksi tersebut hanya bersifat formal. Hasil ini tidak sesuai dengan hasil penelitian oleh Khairizah et al. (2015) serta Siswanto \& Hamid (2017) yang menyatakan bahwa kepemimpinan konsultasi memiliki pengaruh terhadap kinerja karyawan.

Kepemimpinan partisipasi dalam penelitian ini berpengaruh positif terhadap kinerja karyawan dikarenakan dalam perusahaan media, setiap kegiatan atau pekerjaan mutlak membutuhkan kontribusi dari tenaga kerja, terutama yang berhubungan dengan berita maupun penciptaan konten lainnya, sehingga setiap ide atau kontribusi dari tenaga kerja sangat dihargai dan didukung. Hasil tersebut sesuai dengan penelitian oleh Iqbal et al. (2015), Habeeb \& Ibrahim (2017), serta Siswanto \& Hamid (2017).

Kepemimpinan delegasi dalam penelitian ini berpengaruh positif terhadap kinerja karyawan disebabkan oleh fakta bahwa di dalam perusahaan media, tugas atau kebijakan yang berhubungan dengan konten seringkali membutuhkan kreativitas yang tinggi, sehingga langkah yang paling baik adalah mendelegasikan tugas dan tanggung jawab untuk membuat keputusan tersebut kepada tenaga kerja yang memiliki kemampuan yang sesuai dengan tugas tersebut. Pekerjaan jurnalistik yang membutuhkan independensi dalam pengambilan keputusan agar mendapatkan berita secara cepat dan akurat juga menjadi salah satu alasan kepemimpinan delegasi digunakan. Hasil tersebut sesuai dengan hasil penelitian oleh Basit et al. (2017), Prasetya et al. (2017), serta Siswanto \& Hamid (2017).

Gaya kepemimpinan yang ideal untuk diterapkan di perusahaan yang bergerak dalam industri media massa menurut hasil penelitian ini adalah gaya kepemimpinan partisipasi dan delegasi, karena dalam industri tersebut dituntut independensi yang tinggi dari tenaga kerjanya, serta kreativitas dan inovasi dalam mencari atau menyusun konten media. Gaya kepemimpinan instruksi dirasakan terlalu mengekang independensi dan kreativitas tenaga kerja di perusahaan media, sehingga sangat tidak cocok untuk diterapkan; sedangkan gaya kepemimpinan konsultasi meskipun memberikan kebebasan dalam derajat tertentu, masih dianggap tidak cukup kuat untuk memengaruhi kinerja tenaga kerja dalam perusahaan media karena sifatnya yang masih bergantung kepada sosok pemimpin dan sifatnya yang cenderung birokratif sangat memperlambat kinerja tenaga kerja.

Secara keseluruhan, apabila seorang pemimpin mengkombinasikan seluruh gaya kepemimpinan di atas, maka terdapat pengaruh yang signifikan terhadap kinerja karyawan, karena dalam situasi tertentu dibutuhkan gaya kepemimpinan tertentu pula (Manning \& Curtis, 2012), sehingga dapat dijelaskan bahwa gaya kepemimpinan secara keseluruhan merupakan suatu fleksibilitas kepemimpinan yang ditunjukkan sesuai dengan situasi dan kondisi yang ada.

\section{SIMPULAN DAN SARAN}

\subsection{Simpulan}

Kesimpulan secara khusus atau spesifik dalam penelitian ini adalah gaya kepemimpinan instruksi dan konsultasi tidak memiliki pengaruh terhadap kinerja karyawan Ayo Media Network, karena sifat dari perusahaan itu sendiri yang bergerak dalam industri media sehingga gaya kepemimpinan tersebut kontraproduktif dan tidak digunakan. Berbeda dengan hal tersebut, gaya kepemimpinan partisipasi dan delegasi memiliki pengaruh yang positif terhadap kinerja karyawan karena Ayo Media Network sangat bergantung kepada partisipasi aktif dari tenaga kerjanya untuk menciptakan konten maupun berita, sehingga mendelegasikan sebagian besar tugas dan tanggung jawabnya kepada tenaga kerjanya. Selain itu, dari hasil penelitian dapat juga dijelaskan bahwa hipotesis 1 dan 2 ditolak karena kepemimpinan instruksi dan konsultasi tidak berpengaruh terhadap kinerja, sedangkan hipotesis 3 dan 4 diterima karena kepemimpinan partisipasi dan delegasi memiliki pengaruh terhadap kinerja.

Kesimpulan secara umum yang dapat diambil adalah bahwa gaya kepemimpinan dapat dipastikan memiliki pengaruh terhadap kinerja seorang karyawan, namun bentuk dari pengaruh tersebut ataupun gaya kepemimpinan mana yang berpengaruh sangat bergantung kepada berbagai macam faktor, seperti 
budaya organisasi yang ada di suatu perusahaan, bentuk dari perusahaan itu sendiri, serta industri tempat perusahaan tersebut berada.

\subsection{Saran}

Saran yang diberikan oleh penelitian ini adalah perlunya partisipasi aktif dari pemimpin terhadap tenaga kerjanya, karena berdasarkan hasil penelitian ditemukan bahwa tenaga kerja terlalu independen dan diperlukan suatu arahan untuk menghindari terjadinya kesalahan. Selain itu, diharapkan adanya penelitian lebih lanjut di perusahaan media lain untuk mendapatkan perbandingan yang lebih baik mengenai pengaruh gaya kepemimpinan terhadap kinerja karyawan.

\section{REFERENSI}

Bangun, W. (2012). Manajemen sumber daya manusia (1st ed.). Erlangga

Basit, A., Sebastian, V., \& Hassan, Z. (2017). Impact of leadership syle on employee performance (Case study on a private organization in Malaysia). International Journal of Accounting \& Business Management, Vol.5(2), 112-130. DOI: 24924/ijabm/2017.11/v5.iss2/112.130

Fajrin, I. Q., \& Susilo, H. (2018). Pengaruh gaya kepemimpinan terhadap kinerja karyawan dengan motivasi kerja sebagai variabel intervening (Studi pada karyawan Pabrik Gula Kebon Agung Malang). Jurnal Administrasi Bisnis, Vol.61(4), 117-124. http://administrasibisnis.studentjournal.ub.ac.id/index.php/jab/article/viewFile/2630/3024

Habeeb, M. Y., \& Ibrahim, Y. (2017). Effect of leadership style on employee performance in Nigerian universities. Global Journal of Management and Business Research: A Administration and Management, Vol. 17(7), 27-33. https://globaljournals.org/gjmbr_volume17/4-effects-ofleadership-style.pdf

Ing'ollan, D. N., \& Roussel, J. (2017). Influence of leadership style on employees' performance: A study of Turkana County, Kenya. International Journal of Business and Social Science, Vol.8(7), 82-98. http://ijbssnet.com/journals/vol_8_no_7_july_2017/9.pdf

Iqbal, N., Anwar, S., \& Haider, N. (2015). Effect of leadership style on employee performance. Arabian Journal of Business and Management Review, Vol. 5(5), 1-6. doi:10.4172/22235833.1000146

Jamaludin, A. (2017). Pengaruh gaya kepemimpinan terhadap kinerja karyawan PT Kaho Indahcitra Garment Jakarta. Journal of Applied Business and Economics, Vol. 3(3), 161-169. http://dx.doi.org/10.30998/jabe.v3i3.1767

Khairizah, A., Noor, I., \& Suprapto, A. (2015). Pengaruh gaya kepemimpinan terhadap kinerja aryawan (Studi pada karyawan di Perpustakaan Universitas Brawijaya Malang). Jurnal $\begin{array}{llll}\text { Administrasi Publik, } & \text { Vol. } & 3(7), & 1268-1272 .\end{array}$ http://administrasipublik.studentjournal.ub.ac.id/index.php/jap/article/view/950

Khajeh, E. H. (2018). Impact of leadership styles on organization performance. Journal of Human Resources Management Research, Vol. 2018, 1-10. doi:10.5171/2018.687849

Kotter, J. P. (2014). Accelerate: Building strategic agility for a faster-moving world. Free Press

Kurniawan, D. P. (2018). Pengaruh gaya kepemimpinan terhadap kinerja karyawan Percetakan Dimas, Kota Palembang. Jurnal Ilmiah Manajemen Bisnis dan Terapan, Vol. 15(1), 33-48. DOI: https://doi.org/10.29259/jmbt.v15i1.5882

Mangkunegara, A. P. (2011). Manajemen sumber daya manusia. Remaja Rosdakarya

Manning, G., \& Curtis, K. (2012). The art of leadership. McGraw-Hill

Maryam. (2017). Pengaruh gaya kepemimpinan terhadap kinerja pegawai pada Kantor Kecamatan Gilireng Kabupaten Wajo. Jurnal Idaarah, Vol. 1(2), 200-212. DOI: https://doi.org/10.24252/idaarah.v1i2.4264

Mawoli, M. A., Mohammed, T. H., \& Sarkin-Daji, B. D. (2013). Leadership styles, job performance, public health institutions, federal medical centre, private health institutions, Lapai. Journal of $\begin{array}{llll}\text { Management } & \text { Science, } & \text { Vol. } & 4(1),\end{array}$ https://papers.ssrn.com/sol3/papers.cfm?abstract_id=3065878 
Otieno, B. N., \& Njoroge, J. G. (2019). Effects of leadership styles on employee performance: Case of Technical University of Kenya. International Journal of Education and Research, Vol. 7(6), 115-132. https://www.ijern.com/journal/2019/June-2019/11.pdf

Prasetya, D. W., Wasiati, I., \& Azhari, A. K. (2017). Pengaruh kepemimpinan delegatif terhadap kinerja pegawai pada Kantor Dinas Kependudukan dan Pencatatan Sipil Kabupaten Jember. International Journal of Social Sciences and Business, Vol. 1(3), 197-208. doi:http://dx.doi.org/10.23887/ijssb.v1i3.11835

Saputro, G. B., \& Siagian, H. (2017). Pengaruh gaya kepemimpinan terhadap kinerja karyawan melalui variabel intervening motivasi kerja di Head Office PT Marifood. AGORA, Vol. 5(3), 18. https://media.neliti.com/media/publications/135024-ID-pengaruh-gaya-kepemimpinanterhadap-kine.pdf

Sedarmayanti. (2017). Manajemen sumber daya manusia. Refika Aditama

Siswanto, R. D., \& Hamid, D. (2017). Pengaruh gaya kepemimpinan terhadap kinerja karyawan (Studi pada karyawan Divisi Human Resource Management Compensation and Benefits PT Freeport Indonesia). Jurnal Administrasi Bisnis, $\quad$ Vol. 42(1), 189-198. http://administrasibisnis.studentjournal.ub.ac.id/index.php/jab/article/view/1676

Thoha, M. (2012). Perilaku organisasi: Konsep dasar dan implikasinya. Raja Grafindo Persada

Waruwu, K., \& Yunita, M. (2019). Pengaruh gaya kepemimpinan dominan (Instruksi, konsultasi, partisipatif, dan delegasi) terhadap kinerja karyawan PT Kelola Jasa Artha Cabang Medan. $\begin{array}{lllll}\text { Jurnal Manajemen } \quad \text { Tools, } & \text { 45-52. }\end{array}$ http://jurnal.pancabudi.ac.id/index.php/JUMANT/article/view/690/653 